\title{
Antecedents of E-SPT Receipt to Increase Compliance of Medium Business Taxpayers in Denpasar, Bali-Indonesia
}

\author{
I Nyoman Senimantara $^{\# 1}$, Anak Agung Ayu Erna Trisnadewi ${ }^{* 2}$, Ni Made Rustini ${ }^{\# 3}$ \\ ${ }^{\#}$ Faculty of Economics and Business \& Warmadawa University Denpasar,Bali -Indonesia
}

\begin{abstract}
Directorate General of Taxes, need to modernize tax administration. Taxpayers are currently able to fulfil their online tax reporting obligations, known as e-filing. Because the submission is online, the Notification Letter (SPT) submitted must also be in electronic form or e-SPT. Electronic reporting of tax obligations is expected to increase taxpayer compliance. The adoption of e-SPT in the Taxation sector as an effort to improve taxpayer compliance is interesting to study. In this case, the Technology Acceptance Model (TAM) Theory offers a powerful and simple explanation for the acceptance of technology and the behaviour of its users (Venkatesh, 1999). Based on (Venkatesh, 1999), acceptance of technology is determined by individual perceptions and intentions which will ultimately shape a person's behaviour in accepting a technology, namely e-SPT. This study aims to determine how the effect of taxpayer compliance antecedents in the perspective of the Technology Acceptance Model. This research was conducted on 90 MSME taxpayers registered at the Tax Service Office (KPP) Pratama throughout Denpasar City using PLS-SEM analysis, with the help of SmartPLS 3.0 Software. The results show that e-SPT self-efficacy can act as an antecedent in an effort to increase perceptions of behavior in using e-SPT in increasing tax reporting administration compliance as mandated by law.
\end{abstract}

Keywords: e-SPT Self-Efficacy, Perceived Ease of Use, Perceived Usefulness, Intention to behave, Acceptance of $e-S P T$.

\section{INTRODUCTION}

Tax is the main source of state revenue. Various regulatory reforms and tax administration have been carried out by the government through the Directorate General of Taxes (DGT). One of the regulations to modernize tax administration is through the Electronic Annual Tax Return. Electronic Annual Tax Returns can improve taxpayer compliance to pay their tax obligations. Taxpayers are currently able to fulfill their online tax reporting obligations, known as e-filing. Because the submission is online, the Notification Letter (SPT) submitted must also be in electronic form or e-SPT

Directorate General of Taxes (DGT) in the Regulation of the Directorate General of Taxes Number PER-03 / PJ / 2015 Concerning the Submission of Electronic Government Letters, Electronic Annual Tax Returns are electronic documents of Annual Tax Returns / Notifications (SPT) which can be obtained from applications provided by DGT is called e-SPT. The E-SPT was approved by the DGT on February 13, 2005 with the hope that taxpayers can report or submit their obligations effectively and efficiently. Thus, the use of e-SPT will increase the realization of tax revenues, particularly Income Tax (PPh 21) and Value Added Tax (VAT).

Furthermore, the Ministry of Finance of the Republic of Indonesia stated that e-SPT has advantages such as; (1) reporting or submitting an SPT or Annual Tax Return can be done quickly and safely, because the documents are in the form of a CD/disk, (2) well-organized tax data, (3) the e-SPT application system regulates taxation company data correctly and systematically, (4) calculations are carried out quickly and precisely by a computer, (5) convenience in making tax reports, (6) data prepared by taxpayers will always be complete because the numbering form is based on a computer system, (7) ) without paper.

Even though the government through the DGT has issued e-SPT regulations, until the March 2020 period, data shows that: Annual SPT reports that have been submitted have reached 6.2 million. It can be further explained that $34.2 \%$ of all reports are submitted via DGT's e-filing. Meanwhile, those who submitted their SPT manually fell by $5 \%$. This shows that DGT's electronic SPT service is getting better. Based on this phenomenon, research on the use of e-SPT is interesting to re-examine, given the importance of using e-SPT for taxpayers and 


\section{DOI: $10.51386 / 25815946 /$ ijsms-v4i6p105}

also for authorities.

Research on the use of technology has been carried out by so many researchers, for example; (Akhter, Baabdullah, Dutta, \& Kumar, 2018) which stated that perception of awareness, availability of resources, perception of images and choice of language did not have a positive influence on interest in using mobile banking. However, perceived ease of use, perceived quality of information and perceived usefulness have positive effects on interest in using mobile banking. In addition, in the same study, only perceived ease of use and perceived usefulness had an effect on interest in using mobile banking. According to (Shankar \& Datta, 2018), perceived usefulness, perceived ease of use and self-efficacy have a significant impact on m-payment adoption behavior, however personal innovation and subjective norms have no significant impact. Another study on the use of technology in the field of taxation was conducted by (Chandra \& Rahmawati, 2016) which stated that perceptions of ease of use, computer self-efficacy had a positive and significant impact on interest in using e-SPT.

The adoption of e-SPT in the Taxation sector as an effort to improve taxpayer compliance is interesting to study. In this case, the Technology Acceptance Model (TAM) Theory offers a powerful and simple explanation for the acceptance of technology and the behavior of its users(Venkatesh, 1999). Based on (Venkatesh, 1999), acceptance of technology is determined by individual perceptions and intentions which will ultimately shape a person's behavior in accepting a technology, namely e-SPT. Venkatesh (1999) states that there are two main concepts that are believed in user acceptance, namely perceived usefulness and perceived ease of use. Perceived usefulness is defined as a person's level of belief that the use of an information system improves performance in his work. Perceived Ease of Use is defined as a person's level of confidence that the use of information system technology will be easy and does not require hard effort.

Previous research that has been done still has conflicting results, as the results of research from Srite, Thatcher, \& Galy (2008) which examines the factors of perception and computer use (use of information technology) through the external variable TAM (computer anxiety, personal innovation, and confidence). Themselves on the computer). The findings show that: (a) perceived ease of use is a strong positive predictor of IT use, but perceived ease of use does not show a direct effect on information technology use, (b) personal innovativeness has a positive effect on perceived ease of use and perceived usefulness, (c) computer anxiety has a negative effect on perceived usefulness and perceived ease of use,

Users of the E SPT application are those who already have a Taxpayer Identification Number (NPWP), so they are the taxpayers. Taxpayers themselves are those who are already working and who are already earning and are eligible to pay taxes. Taxpayers who implement the E SPT application are expected to feel easier, safer, more confident in their tax reporting and will not become taxpayers who do not pay taxes. Medium-sized enterprises are one of the sectors of the MSME category located in Denpasar City. Medium business managers are required to pay taxes and make tax reports. Medium business managers are one of the users of SPT in making tax reports because medium business managers have the responsibility to pay and make tax reports, but found the fact that almost the majority of taxpayers, especially managers of medium-sized businesses still report the SPT manually. Medium business managers can more easily complete tax reports, with technological advances and the application of E SPT, so in this study researchers used medium business managers as research objects.

This study is an adaptation of Venkatesh (1999) by including an external variable, namely e-SPT SelfEfficacy as an antecedent of technology acceptance in tax administration. Thus, researchers wish to prove that perceived usefulness and perceived ease of use can affect the intention of taxpayers in Denpasar City in acceptance of the use of e-SPT in improving the administration of reporting tax obligations. Based on the above background, the purpose of this study is to find out how the antecedents influence the use of e-SPT in the perspective of Technology Acceptance Model Theory.

\section{LITERATURE REVIEW AND HYPOTHESIS}

Technology Acceptance Model Theory (TAM)

The adoption of information technology systems by an organization or public institution can be predicted with several evaluation model theories that have been developed. To date. The theory of evaluation models that 
have been used to measure the acceptance of information technology systems are End User Computing Satisfaction, Task Technology Fit, Human Organization-Technology (HOT) and TAM Theory (Technology Acceptance Model).(Sayekti \& Turna, 2016).

TAM theory is a development of Reasoned Action Theory (TRA). This theory was developed by Fishbein and Ajzen (1975, 1980). This theory emphasizes the psychological aspect, namely attitude. Psychologically, attitudes can be used to measure behavioural components, are able to make a difference between beliefs or attitudes, and can determine external stimuli. The emphasis of this TAM theory is more on the perception of ease for users and usefulness that will be used in predicting a person's attitude in using information systems.(Davis, Bagozzi, \& Warshaw, 1989). It can be concluded that the TAM model has a wider scope when compared to the TRA . model (Fatmawati, 2015; Hakim \& Nurkamid, 2017).

TAM (Technology Acceptance Model) is an information technology system that can explain a person's acceptance of the use of information technology systems. The purpose of TAM is to be able to explain the main factors of information technology user behavior towards the acceptance of information technology users themselves. This model illustrates that users of information systems will be influenced by the usefulness variable and the ease of use variable, both of which have high determinants and empirically tested validity. TAM believes that the use of information systems will improve the performance of individuals or organizations, besides that the use of information systems is relatively easier and does not require hard work to use it. (Hartono, 2013).

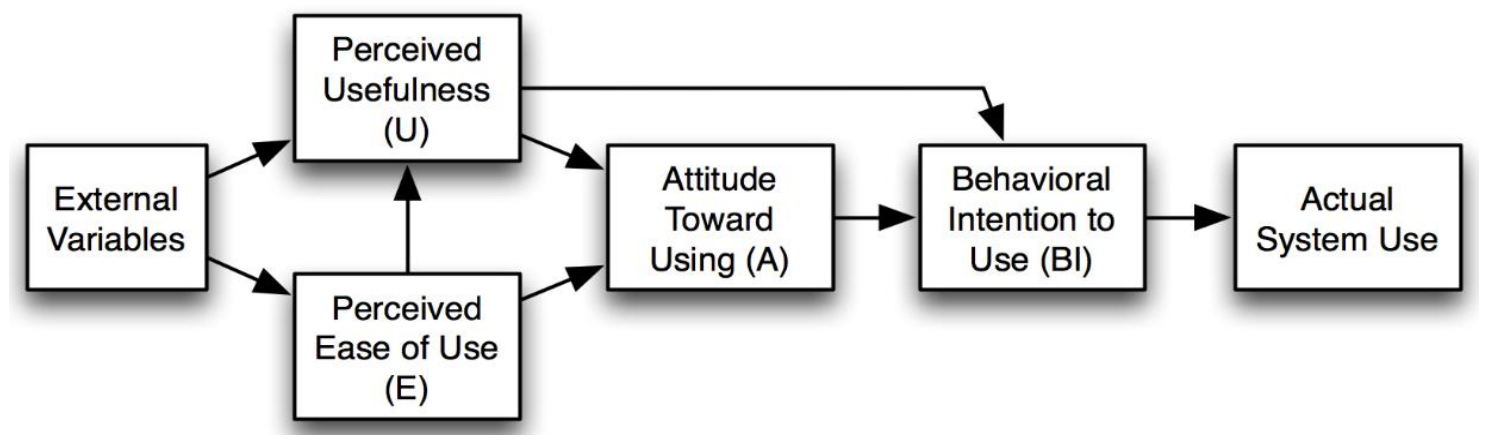

Figure 1 TAM Davis Model Theory (1989)

However, in subsequent developments, a number of researchers in the field of TAM did not include the attitude variable in their analysis, because based on empirical facts found a weak attitude mediating relationship between belierfs and behavior intention. (Venkatesh, 1999).

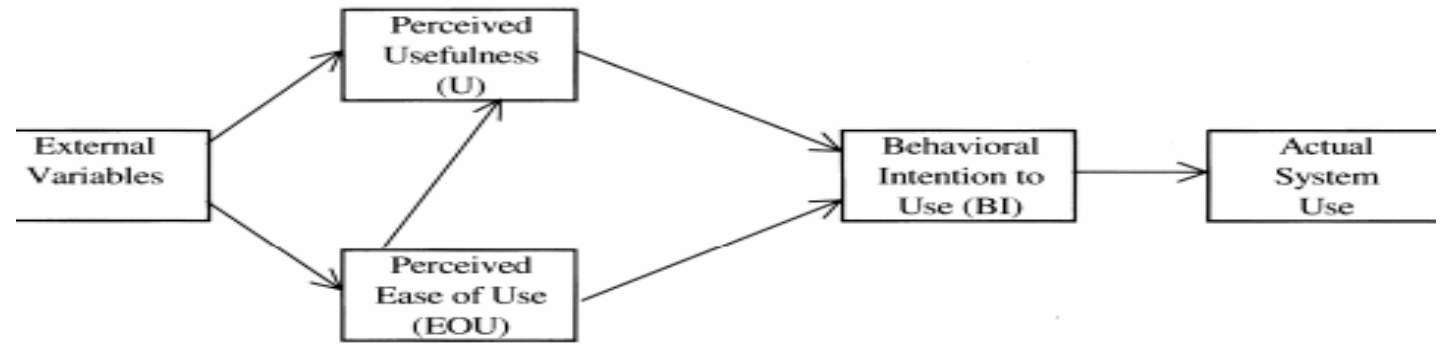

Figure 2 Venkatesh TAM Theory Model (1999)

E-SPT Self-Efficacy as Antecedent of Use of E-SPT.

Bandura, (1977)explains that self-efficacy is a person's assessment of his ability to organize and decide the necessary actions with the aim of achieving the desired performance. The main source of self-efficacy is perception and interpretation, both physically and emotionally. Self-efficacy plays a role in influencing the motivational process through a number of individual efforts and how long individuals work when there are obstacles. Individuals with low self-efficacy will undermine motivation through feeling that they are unable to complete the task before trying it.Davis et al., (1989)revealed that self-efficacy plays a role in influencing the 


\section{DOI: $10.51386 / 25815946 /$ ijsms-v4i6p105}

motivational process through the amount of effort that individuals will use and how long they continue to work on their tasks when there are obstacles. Individuals with low self-efficacy will undermine motivation through feeling that they are unable to complete the task before the task is attempted.

Perceived Ease of Use and Perceived Usefulness.

(Davis et al.,1989) states that perceived usefulness is a person's level of belief that the use of a particular system will improve his job performance. Perceived usefulness is defined as the usability of a technology so that if the usefulness of a technology is in doubt, someone's intention to use it will not appear. Next(Davis et al., 1989) explains that perceived ease of use is the extent to which a person believes that using a technology will be free from effort. (Davis et al., 1989; Venkatesh, 1999) stated that the Perceived Ease of Use describes the impact on the level of behaviour through two causes, namely the direct impact on the level of behaviour and the indirect impact on behaviour through perceived usefulness. Several researchers have replicated Davis. research model (Davis et al., 1989) to provide empirical evidence on the positive influence of Perceived Ease of Use and Perceived Usefulness on Intentions and Behaviors for using information technology systems (Adams, Nelson, \& Todd, 1992; Al-Haderi, 2013; Hendrickson, Massey, \& Cronan, 1993). Next (Szajna, 1996; Venkatesh \& Davis, 1996 and Kanchanatanee, Suwanno, \& Jarernvongrayab, 2014) proves that ease of effect on the use of information systems either directly or indirectly with perceived usefulness.

\section{Intention to Use e-SPT and Real Behavior}

Davis, (1995)explained that behavioral intention is a person's desire (intention) to perform a certain behavior. A person will perform a behavior (behavior) if he has the desire or intention (behavioral intention) to do so. Intentions can also indicate doing a behavior in the future and repeating it at a later date. Next Davis, (1995) also stated that actual system usage is a real condition of system usage. Individuals will be satisfied using the system if they believe that the system is easy to use and can increase their productivity, which is reflected in the real conditions of use.Davis et al., 1989). The form of measurement of actual system usage is the frequency and duration of use of ICT. Actual technology use is measured by the amount of time spent interacting with technology and the frequency with which technology is used.(Ari, 2013). The results of previous studies show that behavioral intention is a good predictor of the use of technology by system users. In addition, there is a strong correlation between behavioral intentions and actual behavior (Venkatesh, Morris, Davis, \& Davis, 2003)

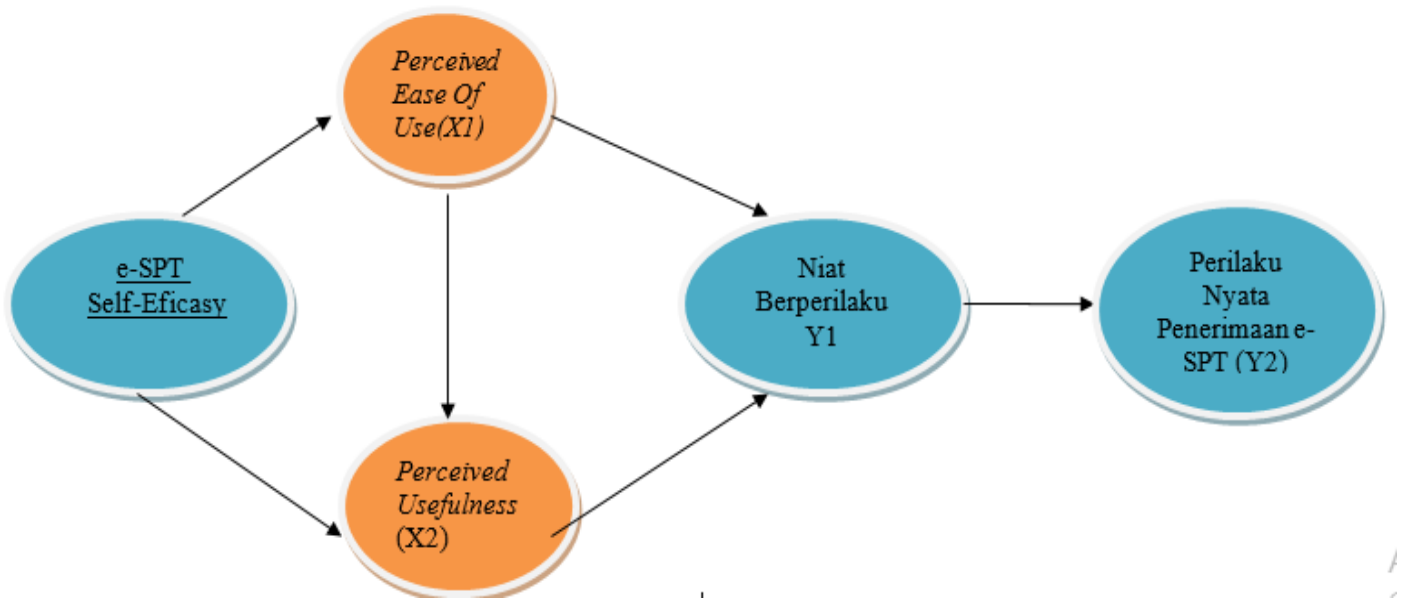

\section{Figure 3 Conceptual Framework}

The effect of the perception of E-SPT Self Efficacy on perceived ease of use

Bandura (1986) introduces two parts of expectations as the main cognitive pressures that direct behavior (Jogiyanto, 2007). The first part of expectations is self-efficacy. The second part of the expectation relates to the results, hereinafter referred to as outcome expectations, which are then widely interpreted as perceived usefulness by many researchers. Self-efficacy considerations in the context of computer use called computer self-efficacy are believed to affect outcomes expectations because one expects results from considerations of how well one can perform the required behavior. The results of Darsono's research (2005) show that computer self-efficacy has an effect on perceived ease of use. This finding is consistent with the findings of Hong et al. (2002), Lewis et al. (2003), and supported by Hassan (2006) who found that computer self-efficacy had a 


\section{DOI: $10.51386 / 25815946 /$ ijsms-v4i6p105}

positive effect on perceived ease of use. Research by Thomson et al. (2006), Hassan (2007), and Srite et al. (2008) also found that computer self-efficacy has an effect on perceived ease of use (perceived ease of use). Based on the theory and study of the research results of the researchers above, the research hypotheses can be proposed as follows: (2008) also found that computer self-efficacy has an effect on perceived ease of use (perceived ease of use). Based on the theory and study of the research results of the researchers above, the research hypotheses can be proposed as follows: (2008) also found that computer self-efficacy has an effect on perceived ease of use (perceived ease of use). Based on the theory and study of the research results of the researchers above, the research hypotheses can be proposed as follows:

H1: E-SPT Self-Efficacy positive effect on the perceived ease of use of e-SPT

The effect of the perception of E-SPT Self - Efficacy on perceived usefullness

Computer self-efficacyis an important determinant for an individual's decision to use computer technology (Hill et al, 1987). Compeau and Hinggins (1995) and Chang et al. (2009) found that the higher the individual's computer self-efficacy, the higher the expectations felt by the individual. Ramayah and Aafaqi (2004). Lopes and Manson (1997), Hong et al. (2002), Darsono (2005), and Adiwibowo et al. (2006) also found that computer self-efficacy is positively related to perceived usefulness. Based on the theory and study of the research results of the researchers above, the research hypotheses can be proposed as follows:

H2: E-SPT Self-Efficacy positive effect on perceived usefulness of e-SPT

Effect of Perceive Easy of Use on Perceive Usefullbess of e-SPT application.

Davis et al. (1989) stated that the results of the use of information systems will not be maximized or may not even be achieved because of resistance or rejection by users of information systems, this is determined by two basic variables that together affect the desire to use and will then affect the use of the system. the. Pramuki and Ayu (2020) show that there is a strong relationship between the perceived ease of use (PEU) variable and perceived usefulness (PU) in the use of information systems, especially social media information technology for MSME actors in Badung Regency. Furthermore, Adams et al. (1992) showed a positive relationship between ease of use and usefulness. Iqbaria et al. (1995) in their research by showing the effect of perceived ease of use (PEU) on perceived usefulness (PU). Based on the theory and study of the research results of the researchers above, the research hypotheses can be proposed as follows:

H3: Perceive Easy of Use has a positive effect on perceived usefullness) e-SPT

The effect of Perceive Easy of Use on Interest Behavior Usage

Davis (1989) revealed that benefits have a strong relationship with interest in usage behavior because someone in using an information technology system believes that the resulting benefits can improve performance. According to research conducted (Lee \& Wan: 2010) the significant effect of perceived usefulness on interest in using is also evidenced by (Kripanont: 2007, Syarif and Sensuse: 2007). Based on the theory and study of the research results of the researchers above, the research hypotheses can be proposed as follows:

H4: Perceive Easy of Use has a positive effect on interest in using the e-SPT application

The effect of Perceive Usefulness on Behavioral Intention of Use.

Davis (1989) revealed that perceived benefits have a strong relationship with interest in usage behavior because someone in using an information technology system believes that the resulting benefits can improve performance. According to research conducted (Lee \& Wan: 2010) the significant effect of perceived usefulness on interest in using is also proven by Pramuki and Ayu (2020). Based on the theory and study of the research results of the researchers above, the research hypotheses can be proposed as follows:

H5: Perceive Usefulness has a positive effect on interest in using the e-SPT application.

The effect of behavioral intentions on the use of e-SPT applications on medium-sized business managers in Denpasar City.

Behavioral intention is a person's desire (interest) to carry out a certain behavior. A person will perform a behavior (behavior) if he has the desire or interest to do so (Jogiyanto, 2007). The higher the individual's interest in using technology, the individual will continue to use the technology in submitting the SPT, namely e-SPT. Therefore, interest in the use of e-SPT has a strong influence on the use of e-SPT. Other studies also prove that there is interest in the use of a positive effect on the use of the e-filing system (Dasera, Zaitul and Rahmawati, 
2014). Based on the theory and study of the research results of the researchers above, the research hypotheses can be proposed as follows:

H6: Intention to apply in the Use of E-SPT has a Positive Effect on the Use of E-SPT

\section{III.RESEARCH METHODS}

This study uses quantitative methods. This study aims to analyze the causal relationship used to explain the effect of computer self-efficacy as an antecedent of acceptance of tax technology, namely e-SPT as an effort to increase taxpayer compliance. The survey was conducted using a random sample method on 90 MSMEs in Denpasar City. The questionnaire consists of a 5-point Likert scale range from strongly disagree (1) to strongly agree (5) and the model variables consist of E-SPT Self-Efficacy, Perceived Ease of Use, Perceived Usefulness, Behavioral Intentions and E-SPT Acceptance. To increase the validity of the content, the scale from the previous study was adapted as the basis of measurement for each variable in the modelVenkatesh, (1999)which has been built from previous research. Perception of E-SPT Self-efficacy is measured by 9 question items developed byIgbaria \& Iivari, (1995) To assess the extent to which Medium Enterprises believe that using ESPT can improve their tax compliance, then Perceived ease of use is measured by adapting the 6 questions developed by Davis,(1995), Fatmawati, (2015) and Ari, (2013)to assess the extent to which medium-sized businesses believe that using E-SPT will make it easier to carry out their tax obligations. Perceived usefulness is also measured by adapting the 6 questions developed byDavis, (1995), Fatmawati, (2015) and Ari, (2013)to assess the extent to which Medium Enterprises believe that using E-SPT will improve their tax compliance. Behavioral intention is measured by adapting the 5 questions developed by $\mathrm{Hu}$, Chau, Liu Sheng, \& Tam, (1999), Weng, Yang, Ho, \& Su, (2018) and Ari, (2013)to assess the desire of medium-sized businesses to use ESPT in carrying out their tax obligations. Finally, the perception of E-SPT acceptance is measured by adapting the 5 questions developed byDavis et al., (1989), Ari, (2013), Venkatesh et al., (2003) and Hanggono, (2015) to assess the real actions taken by medium-sized business actors in using E-SPT. This study uses PLS with the help of SmartPLS 3.0 software, because it uses a model based on a conceptual framework, which shows a causal relationship between e-SPT self-efficacy, Perceived Ease Of Use (X1), Perceived Usefulness, Behavioral Intentions and Acceptance of e-SPT. The analysis tool is considered suitable, because it can evaluate the quality of the data based on the measurement model, and is seen as a combination of regression and factor analysis. In addition, it can analyze reflective and formative measurement models.

\section{IV.RESULT AND DISCUSSION}

90 questionnaires were randomly distributed and returned intact and complete so that they could be processed further. The characteristics of the respondents in this study include age, education, length of business and gender of medium-sized business managers as shown in table 1 below:

Table 1 Demographic Characteristics of Respondents

\begin{tabular}{|c|l|c|c|}
\hline \multicolumn{7}{|l|}{ Characteristics } & Frequency & Percent \\
\hline \multirow{5}{*}{ Age } & Under 30 years old & 7 & 7.78 \\
\cline { 2 - 4 } & $31-40$ years old & 17 & 18.89 \\
\cline { 2 - 4 } & 41-50 years old & 30 & 33.33 \\
\cline { 2 - 4 } & 51-60 years old & 28 & 31.11 \\
\cline { 2 - 4 } & Over 60 years old & 8 & 8.89 \\
\hline \multirow{5}{*}{ Education } & up to high school & 9 & 10.3 \\
\cline { 2 - 4 } & Diploma & 27 & 30 \\
\cline { 2 - 4 } & S1 & 48 & 53.33 .00 \\
\cline { 2 - 4 } & S2 & 8 & 6.67 \\
\hline \multirow{5}{*}{ Business Length } & Under 5 years & 17 & 8.89 \\
\cline { 2 - 4 } & 6-10 years & 38 & 18.89 \\
\cline { 2 - 4 } & $11-15$ years old & 62.22 \\
\hline
\end{tabular}




\begin{tabular}{|c|l|c|c|}
\multirow{2}{*}{} & $16-20$ years old & 15 & 16.67 \\
\cline { 2 - 4 } & Over 20 years & 12 & 13.33 \\
\hline \multirow{3}{*}{ Gender } & Woman & 27 & 30 \\
\cline { 2 - 4 } & Man & 63 & 70 \\
\hline
\end{tabular}

Based on the results of the respondents' demographic answers in table 4.1, it can be explained that 1) the age characteristics of the respondents in this study were dominated by the age range of 41-50 years as many as 30 people or $33.33 \%$. 2) the characteristics of the education level of the respondents in this study were dominated by undergraduate education levels as much as 48 or $53.33 \%, 3$ ) the characteristics of the length of business of the respondents in this study were dominated by 11-15 years as many as 38 or $42.2 \%$ and 4 ) gender characteristics Respondents in this study were dominated by men as many as 63 people or 70 .

Test Measurement Model (Outer Model)

\section{Convergent Validity}

Table 2 Outer Loading Value Estimation Results before Execution

\begin{tabular}{|c|c|c|}
\hline Variable & Indicator & Correlation Value \\
\hline \multirow{9}{*}{ Self Efficacy } & SE.1 & 0.507 \\
\hline & SE. 2 & 0.866 \\
\hline & SE.3 & 0.847 \\
\hline & SE.4 & 0.647 \\
\hline & SE.5 & 0.539 \\
\hline & SE.6 & 0.565 \\
\hline & SE.7 & 0.768 \\
\hline & SE. 8 & 0.624 \\
\hline & SE.9 & 0.809 \\
\hline \multirow{6}{*}{ Perception of Ease } & PM.1 & 0.761 \\
\hline & PM.2 & 0.518 \\
\hline & PM.3 & 0.664 \\
\hline & PM.4 & 0.766 \\
\hline & PM.5 & 0.615 \\
\hline & PM.6 & 0.576 \\
\hline \multirow{6}{*}{ Useful Perception } & PK.1 & 0.680 \\
\hline & PK.2 & 0.760 \\
\hline & PK.3 & 0.622 \\
\hline & PK.4 & 0.783 \\
\hline & PK.5 & 0.772 \\
\hline & PK.6 & 0.755 \\
\hline \multirow{6}{*}{ Intention to Use e-SPT } & N.1 & 0.509 \\
\hline & N.2 & 0.636 \\
\hline & N.3 & 0.843 \\
\hline & N.4 & 0.864 \\
\hline & N.5 & 0.469 \\
\hline & Y.1 & 0.845 \\
\hline
\end{tabular}




\begin{tabular}{|l|c|c|}
\hline \multirow{2}{*}{ Using e-SPT } & Y.2 & 0.665 \\
\cline { 2 - 3 } & Y.3 & 0.781 \\
\cline { 2 - 3 } & Y.4 & 0.717 \\
\cline { 2 - 3 } & Y.5 & 0.504 \\
\hline
\end{tabular}

The results of the calculation of the outer loading value in Table 4.2 show that there are several indicators that do not meet the valid requirements based on the convergent validity criteria, namely the outer loading value is less than 0.60 so it must be removed from the model. The indicators that are removed from the model based on table 4.2 are indicators SE 1, SE 5, SE 6 on the self efficacy variable. PM 2, PM 5, and PM 6 indicators on the perceived convenience variable. Indicators N1 and N5 on the intention variable using e-SPT. Y5 indicator on variables using e-SPT.

Table 3 Outer Loading Value Estimated Result After Execution

\begin{tabular}{|c|c|c|}
\hline Variable & Indicator & Correlation Value \\
\hline \multirow{6}{*}{ Self Efficacy } & SE. 2 & 0.238 \\
\hline & SE.3 & 0.228 \\
\hline & SE.4 & 0.201 \\
\hline & SE.7 & 0.184 \\
\hline & SE.8 & 0.204 \\
\hline & SE.9 & 0.223 \\
\hline \multirow{3}{*}{ Perception of Ease } & PM.1 & 0.459 \\
\hline & PM.3 & 0.337 \\
\hline & PM.4 & 0.475 \\
\hline \multirow{6}{*}{ Useful Perception } & PK.1 & 0.225 \\
\hline & PK.2 & 0.259 \\
\hline & PK.3 & 0.212 \\
\hline & PK.4 & 0.194 \\
\hline & PK.5 & 0.253 \\
\hline & PK.6 & 0.227 \\
\hline \multirow{3}{*}{ Intention to Use e-SPT } & N.2 & 0.387 \\
\hline & N.3 & 0.362 \\
\hline & N.4 & 0.453 \\
\hline \multirow{4}{*}{ Using e-SPT } & Y.1 & 0.404 \\
\hline & Y.2 & 0.239 \\
\hline & Y.3 & 0.302 \\
\hline & Y.4 & 0.349 \\
\hline
\end{tabular}

The results of the calculation of the outer loading value in Table 3 show that all indicators have met the valid requirements based on the discriminant validity criteria, namely the outer loading value above 0.60 . Here's a picture of the model after it was executed. 


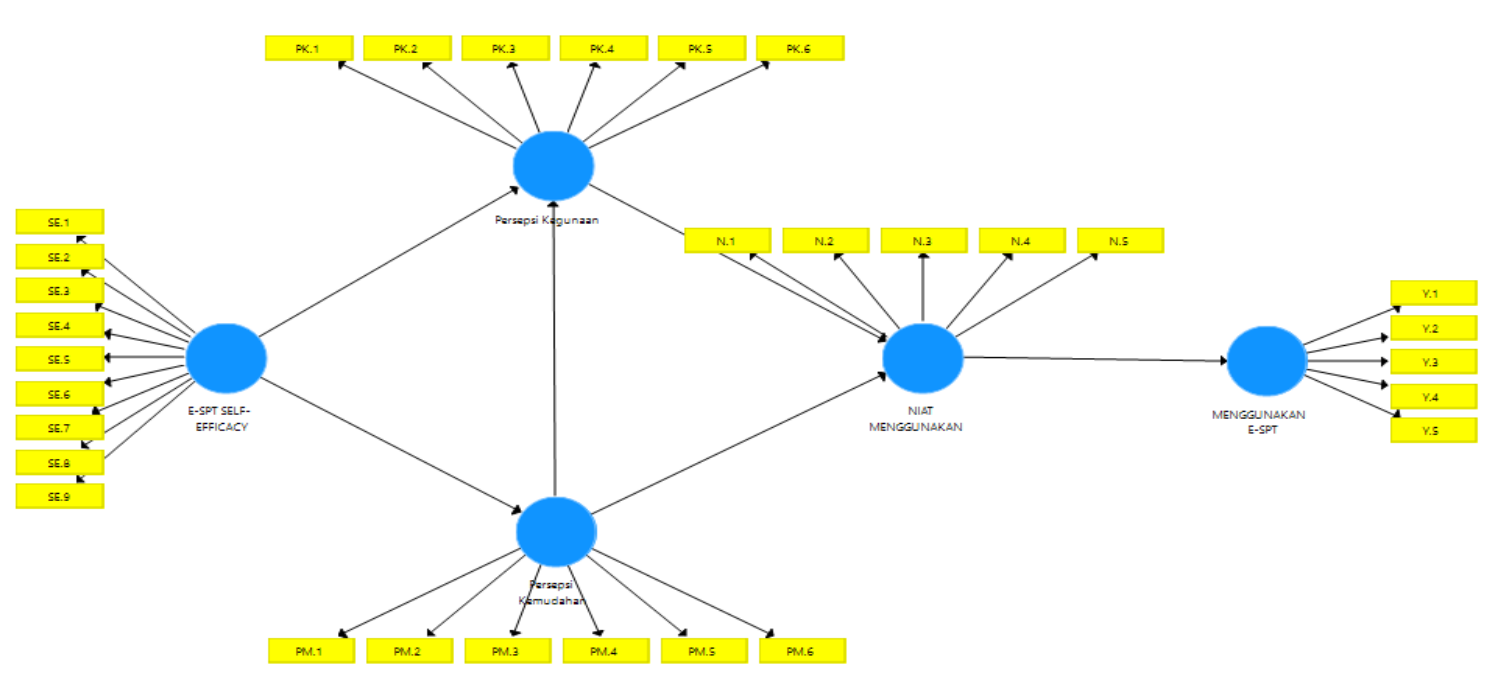

Discriminant Validity

Figure 3 Structural Model

Table 4 Discriminant Validity Test

\begin{tabular}{|l|c|c|c|c|c|c|}
\hline Variable & AVE & AVE & $\begin{array}{c}\text { Self } \\
\text { Efficacy. }\end{array}$ & $\begin{array}{c}\text { Perception of } \\
\text { Ease }\end{array}$ & $\begin{array}{c}\text { Useful } \\
\text { Perceptio } \\
\text { n }\end{array}$ & $\begin{array}{c}\text { Intentio } \\
\mathbf{n}\end{array}$ \\
\hline Self Efficacy & 0.613 & 0.783 & & & & \\
\hline Perception of Ease & 0.617 & 0.765 & 0.682 & & & \\
\hline Useful Perception & 0.535 & 0.713 & 0.433 & 0.703 & & \\
\hline Intention & 0.697 & 0.715 & 0.550 & 0.608 & 0.705 & \\
\hline Use & 0.587 & 0.706 & 0.639 & 0.695 & 0.565 & 0.551 \\
\hline
\end{tabular}

Table 4 shows that the AVE value of all constructs is $>0.50$ and the value of The AVE of each construct ranges from 0.713 to 0.783 , which is greater than the correlation value, which is between 0.433 to 0.765 . so that it meets the valid requirements based on the discriminant validity criteria.

Composite Reliability and Cronbach Alpha

Table 5 Composite Reliability Test and Cronbach Alpha

\begin{tabular}{|c|c|c|}
\hline Variable & Cronbach's Alpha & Composite Reliability \\
\hline Self Efficacy & 0.869 & 0.903 \\
\hline Perception of Ease & 0.710 & 0.828 \\
\hline Useful Perception & 0.824 & 0.873 \\
\hline Intention to use e-SPT & 0.772 & 0.872 \\
\hline Using e-SPT & 0.768 & 0.850 \\
\hline
\end{tabular}

Table 5 shows that the value of composite reliability and Cronbach Alpha of each construct has shown a value greater than 0.60 so that it meets the reliable requirements based on the composite reliability criteria.

Evaluation of Structural Models Through R-Square (R2)

Table 6 Evaluation of the Inner Structural Model

\begin{tabular}{|l|c|c|}
\hline & R Square & R Square Adjusted \\
\hline Using e-SPT & 0.304 & 0.291 \\
\hline
\end{tabular}


Table 6 shows that the R2 value of fraud detection is 0.304 based on Chin's criteria (Ghozali, 2021), then the model includes moderate model criteria, the meaning is the variation of self efficacy, perceived ease, perceived usefulness, and intention to use e-SPT by $69.6 \%$ against using e-SPT.

Table 7 Path Analysis and Statistical Testing

\begin{tabular}{|l|c|c|c|c|}
\hline & $\begin{array}{c}\text { Original } \\
\text { Sample }\end{array}$ & T.Statistics & P.Values & Information \\
\hline $\begin{array}{l}\text { E-Spt Self-Efficacy -> Perception of } \\
\text { Usefulness }\end{array}$ & 0.601 & 5,974 & 0.000 & Significant \\
\hline $\begin{array}{l}\text { E-Spt Self-Efficacy -> Perception of } \\
\text { Ease }\end{array}$ & 0.682 & 10,960 & 0.000 & Significant \\
\hline $\begin{array}{l}\text { Perception of Ease -> Perception of } \\
\text { Usability }\end{array}$ & 0.193 & 1,480 & 0.139 & Not significant \\
\hline $\begin{array}{l}\text { Usability Perception -> Intention to } \\
\text { Use }\end{array}$ & 0.060 & 0.430 & 0.667 & Not significant \\
\hline $\begin{array}{l}\text { Perception of Ease -> Intention to } \\
\text { Use }\end{array}$ & 0.572 & 4,513 & 0.000 & Significant \\
\hline Intention to Use -> Using E-Spt & 0.551 & 5.085 & 0.000 & Significant \\
\hline
\end{tabular}

The effect of E-SPT self efficacy on perceived ease

E-SPT self efficacy has a positive effect of 0.682 on perceived ease and the relationship is significant at the 0.05 level with a t-statistical value of 10.960 which is greater than the t-table value of 1.96 , it can be concluded that the increasing variation of e-SPT self -Efficacy can significantly increase perceived easy of use in using e-SPT so that hypothesis 1 is supported in this study. This phenomenon can occur because medium-sized business actors have high confidence that e-SPT is easy to use in the completion of tax reporting administration. The results of this study support the research conducted by Darsono (2005) which shows that computer self-efficacy has an effect on perceived ease of use. This finding is consistent with the findings of Hong et al. (2002), Lewis et al. (2003),

\section{Effect of E-SPT self efficacy on perceived usefulness.}

E-SPT self-efficacy has a positive effect of 0.601 on perceived usefullness and the relationship is significant at the 0.05 level with a t-statistical value of 5.974 which is greater than the t-table value of 1.96 , it can be concluded that the increasing variation of self-e-SPT efficacy can significantly increase the perceived usefullness of the use of e-SPT applications so that hypothesis 2 is supported in this study. This phenomenon can occur because medium-sized business actors have high confidence that the use of e-SPT will provide benefits or uses for the completion of tax reporting administration. The results of this study support the research conducted by Compeau and Hinggins (1995) and Chang et al.

The effect of perceived convenience on perceived usefulness.

Perception of convenience has a positive effect of 0.193 on perceived usefulness and the relationship is not significant at the 0.05 level with a t-statistic value of 1.480 smaller than the t-table value of 1.96 , it can be concluded that the increased variation in perceived easy of use is not can immediately increase the perceived usefulness of the use of e-SPT applications so that hypothesis 3 is not supported in this study. This phenomenon can occur that although medium-sized business actors have the perception that e-SPT is easy to use, but to increase the perception that e-SPT provides these benefits requires a long process, which is caused by limited knowledge and understanding regarding regulations for reporting electronic tax obligations. The results of this study do not support the findings of Adams et al.

\section{The effect of perceived convenience on the intention to use E-SPT}

Perception of convenience has a positive effect of 0.572 on the intention to use e-SPT and the relationship is significant at the 0.05 level with the t-statistical value of 4.513 which is greater than the t-table value of 1.96. 


\section{DOI: $10.51386 / 25815946 /$ ijsms-v4i6p105}

\section{Effect of perceived usefulness on intention to use E-SPT}

Perception of usefulness has a positive effect of 0.060 on the intention to use e-SPT and the relationship is not significant at the 0.05 level with a t-statistical value of 0.430 which is smaller than the t-table value of 1.96 . it can be concluded that the increased variation in perceived usefulness does not necessarily increase the intention to use the e-SPT application so that hypothesis 4 is not supported in this study. This phenomenon can occur because even though medium-sized business actors have the perception that e-SPT provides easy-to-use benefits, but to increase the intention to use e-SPT in reporting tax administration this requires a long process which is caused by the absence of a positive attitude for medium-sized business actors. in using e-SPT. This positive attitude is the main determinant of the increased intention to behave. The results of this study do not support the findings of Davis (1989), Lee \& Wan: (2010) and Pramuki and Ayu (2020) reveal that perceived usefulness or perceived usefulness of benefits has a strong relationship with interest in usage behavior because someone is using a technology system. Information believes that the resulting benefits can improve performance.

\section{Effect of intention to use e-SPT on actions using e-SPT.}

The intention to use the e-SPT has a positive effect of 0.551 on using the e-SPT and the relationship is significant at the 0.05 level with a t-statistical value of 5.085 which is greater than the t-table value of 1.96 , it can be concluded that the increasing intention to use e-SPT, the use of e-SPT has also increased significantly. Dasera, Zaitul and Rahmawati, (2014) provide empirical evidence of the effect of intention on real behavior in the use of e-SPT. This stronger relationship can occur because of the intention to use e-SPT which is implemented by trying to use e-SPT at any time which can assist in the administration of tax reporting, which can directly increase the use of e-SPT to always report tax obligations and access the information provided. by the website of the DGT

\section{CONCLUSIONS, LIMITATIONS AND SUGGESTION}

Based on the findings in this study, it can be concluded that the use of the e-SPT application can be increased by paying attention to the psychological aspects of individual taxpayers, in this case the managers of medium-sized businesses in the TAM model perspective. This study succeeded in validating the TAM theory so that it can be used as a model to predict acceptance behavior for using e-SPT in reporting tax obligations, especially for medium-sized business taxpayers in improving their tax compliance.

Empirically, the results of this study are proven and consistent with previous research that social media self-efficacy is an antecedent of the use of e-SPT. This proves that the perception of medium-sized business managers to use the -SPT in increasing compliance with regard to tax reporting administration is strongly influenced by the confidence of medium-sized businesses to obtain information by accessing the DGT's official website and to be able to use e-SPT in increasing their productivity. With the increase in self-efficacy e-SPT, it will further lead to an increase in perceptions of ease and use and perceptions of benefits which can then jointly increase intentions, and in the end with high intentions will influence medium-sized business actors to use eSPT applications.

This study has limitations, that this study has not classified MSME businesses either in the type of business, the number of assets and the number of employees so that it can affect the generalization results of the study. The next limitation is that this research focuses on Badung Regency, so the generalization of the research is low. For further research, the research area can be expanded further by targeting other districts in Bali. In addition, it is also necessary to pay attention to individual psychological aspects related to the acceptance or use of technology by using different theoretical approaches such as plan behavior theory, attribution theory, motivation theory and also using different research designs such as experimental studies to strengthen aspects of its internal validity.

\section{ACKNOWLEDGMENT}

We, from the research team, would like to thank the leadership of the Faculty of Economics and Business, University of Warmadewa for the funding assistance for this research.

\section{REFERENCES}

[1] Adams, D. A., Nelson, R. R., \& Todd, P. A. (1992). Perceived usefulness, ease of use, and usage of information technology: A replication. MIS Quarterly: Management Information Systems. 


\section{DOI: 10.51386/25815946/ijsms-v4i6p105}

[2] Al-Haderi, S. (2013). The effect of self-efficacy in the acceptance of information technology in the public sector. International Journal of Business and Social Science, 4(9), 188-198.

[3] Akhter, M., Baabdullah, A., Dutta, S., \& Kumar, V. (2018). Consumer Adoption of Mobile Banking Services: An Empirical Examination of Factors According to Adoption Stages. Journal of Retailing and Consumer Services, 43(March), 54-67

[4] Ari, D. P. S. (2013). Pengaruh Technology Acceptance Model Dan Pengembangannya Dalam Perilaku Menggunakan Core Banking System. Jurnal Keuangan Dan Perbankan, 17(2), 267-278.

[5] Bandura, A. (1977). Self-efficacy : Toward a Unifying Theory of Behavioral Change. 84(2), 191-215.

[6] Chandra, I. R., \& Rahmawati, D. (2016). Computer Self Efficacy Terhadap Minat Penggunaan E-SPT Dalam Pelaporan Pajak. Jurnal Nominal, V(3), 72-87. Hartono, J. (200

[7] Compeau, D. R., \& Higgins, C. A. (1995). Computer self-efficacy: Development of a measure and initial test. MIS Quarterly: Management Information Systems.

[8] Davis, F. D. (1995). Perceived Usefulness, Perceived Ease of Use, and User Acceptance of Information Technology. Management Information Systems Research Center, University of Minnesota, 13 No 3(September), 319-340. https://doi.org/10.2307/249008

[9] Davis, F. D., Bagozzi, R. P., \& Warshaw, P. R. (1989). User Acceptance of Computer Technology: A Comparison of Two Theoretical Models. Management Science. https://doi.org/10.1287/mnsc.35.8.982

[10] Fatmawati, E. (2015). Technology Acceptance Model (Tam) Untuk Menganalisis Penerimaan Terhadap Sistem Informasi Perpustakaan. Jurnal Iqra'.

[11] Hakim, M. M., \& Nurkamid, M. (2017). MODEL ADOPSI UKM DI KUDUS TERHADAP E-COMMERCE. Simetris: Jurnal Teknik Mesin, Elektro Dan Ilmu Komputer. https://doi.org/10.24176/simet.v8i1.974

[12] Hanggono, A. A. (2015). Analisis Atas Praktek Tam ( Technology Acceptance Model ) Dalam Mendukung Bisnis Online Dengan Memanfaatkan Jejaring Sosial Instagram. Jurnal Administrasi Bisnis Universitas Brawijaya, 26(1), 1-9.

[13] Hartono, J. (2013). ). Sistem Informasi Keperilakuan Edisi Revisi.

[14] Hendrickson, A. R., Massey, P. D., \& Cronan, T. P. (1993). On the Test-Retest Reliability of Perceived Usefulness and Perceived Ease of Use Scales. MIS Quarterly. https://doi.org/10.2307/249803

[15] Hernandez, B., Jimenez, J., \& Jose Martin, M. (2009). The impact of self-efficacy, ease of use and usefulness on e-purchasing: An analysis of experienced e-shoppers. Interacting with Computers. https://doi.org/10.1016/j.intcom.2008.11.001

[16] Hu, P. J., Chau, P. Y. K., Liu Sheng, O. R., \& Tam, K. Y. (1999). Examining the Technology Acceptance Model Using Physician Acceptance of Telemedicine Technology. Journal of Management Information Systems, 16(2), 91-112. https://doi.org/10.1080/07421222.1999.11518247

[17] Igbaria, M., \& Iivari, J. (1995). The effects of self-efficacy on computer usage. Omega, 23(6), 587-605. https://doi.org/10.1016/0305-0483(95)00035-6

[18] Kanchanatanee, K., Suwanno, N., \& Jarernvongrayab, A. (2014). Effects of Attitude toward Using, Perceived Usefulness, Perceived Ease of Use and Perceived Compatibility on Intention to Use E-Marketing. Journal of Management Research, 6(3), 1. https://doi.org/10.5296/jmr.v6i3.5573

[19] Perpendaharaan, D. J., \& Negara, D. J. K. (2017). Realisasi APBN Tahun Anggaran 2017

[20] Pramuki, Ni Made Wisni Arie dan Ayu, Putu Cita. (2020). Antecedents of the Use of MSME Social Media: In the Perspective of Technology Acceptance Model Theory. International Journal of Contemporary Research and Review, 11(04), 21776-21786. https://doi.org/10.15520/ijcrr.v11i04.800

[21] Sayekti, F., \& Putarta, P. (2016). Penerapan Technology Acceptance Model ( Tam ) Dalam Pengujian Model Penerimaan Sistem Informasi Keuangan Daerah. Jurnal Manajemen Teori Dan Terapan.

[22] Shankar, A., \& Datta, B. (2018). Factors Affecting Mobile Payment Adoption Intention: An Indian Perspective. Vinod Gupta School of Management, 19, 725-895

[23] Szajna, B. (1996). Empirical evaluation of the revised technology acceptance model. Management Science. https://doi.org/10.1287/mnsc.42.1.85

[24] Venkatesh, V. (1999). Creation of favorable user perceptions: Exploring the role of intrinsic motivation. Management Information Systems Research Center, University of Minnesota, 23(2), 239-260. 


\section{DOI: $10.51386 / 25815946 / \mathrm{ijsms}-\mathrm{v} 4 \mathrm{i} 6 \mathrm{p} 105$}

Volume: 4 Issue: 6

[25] Venkatesh, V., \& Davis, F. D. (1996). A Model of the Antecedents of Perceived Ease of Use: Development and Test. Decision Sciences. https://doi.org/10.1111/j.1540-5915.1996.tb01822.x

[26] Venkatesh, V., Morris, M. G., Davis, G. B., \& Davis, F. D. (2003). User Acceptance Of Information Technology: Toward A Unified View. Management Information Systems Research Center, University of Minnesota, 27(3), 425-478.

[27] Wang, Y. S., Wang, Y. M., Lin, H. H., \& Tang, T. I. (2003). Determinants of user acceptance of Internet banking: An empirical study. International Journal of Service Industry Management. https://doi.org/10.1108/09564230310500192

[28] Weng, F., Yang, R.-J., Ho, H.-J., \& Su, H.-M. (2018). A TAM-Based Study of the Attitude towards Use Intention of Multimedia among School Teachers. Applied System Innovation, 1(3), 36. https://doi.org/10.3390/asi1030036 